\title{
The use of malignant serosal fluid as a tumor vaccine in patients with advance malignancies
}

\author{
Suresh Katakkar \\ From 30th Annual Meeting and Associated Programs of the Society for Immunotherapy of Cancer (SITC 2015) \\ National Harbor, MD, USA. 4-8 November 2015
}

\begin{abstract}
After getting approval from IRB 15 patients were treated with the vaccine prepared from their own malignant serosal fluid. This study was done 1990. These were patients who had all conventional chemotherapy and have failed and had progressive disease. The serosal fluid was heat treated under aseptic condition so as to maintain the antigenecity but to lose the virulence of the malignant cells. The fluid then was injected subcutaneously half cc QOD first week and twice week second week and then once week. The patients were informed to report any unusual symptoms such as fever, rash or swelling at the injection site or any systemic effects. The patients were examined every month by the physician and the appropriate radiological work up was done every three months or earlier if needed. All the laboratory work was done to begin with and every fourth week.
\end{abstract}

\section{Results}

One patient with advanced gastric cancer had CR for five years, 2/4 NSCLC had partial response for 6 months, $1 / 4$ breast cancer had PR for 5.8 months, $2 / 3$ ovarian cancer had PR for 7.8 months and $1 / 2$ colon cancer had PR for 4.5 months and 1/1 pancreatic cancer had PR for 4 months. No adverse events were noted other than mild itching in 4 patients at the site of injection. The PR was consider if there was at least $25 \%$ reduction in the metastatic disease. The patient with $C R$ lived for 5 and half years and had died at the age of 95 .

\section{Methodology}

The fluid was heated at 37 degree centigrade for 45 minutes in aliquots of $5 \mathrm{cc}$ test tubes in a water bath. Post heat treatment was analyzed for malignant cells. The culture and sensitivity was done to make sure there no was contamination.

Arizona Hematology Oncology, Tucson, AZ, USA
The study on the fluid was limited as the technology was not advanced then. But now we can determine Exons, cytokines or genetic analysis, microRNAs.

\section{Conclusion}

This initial crude method of making the vaccine was successful in getting response $8 / 15$ patients, 1 patient had very long-term response excluding her PR average of 4 months without any side effects. Now the technology has advanced so we may be able to isolate what antigenic molecule we are injecting or is it the entire cytoskeleton that is needed. Besides the patient who had $\mathrm{CR}$ had gastric cancer and as we now know the cancer genomics is more unique in gastric cancers such personalized therapy may be more specific in gastric cancer.

Published: 4 November 2015

doi:10.1186/2051-1426-3-S2-P439

Cite this article as: Katakkar: The use of malignant serosal fluid as a tumor vaccine in patients with advance malignancies. Journal for ImmunoTherapy of Cancer 2015 3(Suppl 2):P439.

Submit your next manuscript to BioMed Central and take full advantage of:

- Convenient online submission

- Thorough peer review

- No space constraints or color figure charges

- Immediate publication on acceptance

- Inclusion in PubMed, CAS, Scopus and Google Scholar

- Research which is freely available for redistribution

Submit your manuscript at www.biomedcentral.com/submit C) BioMed Central 